\title{
合金一セラミックス分散複合化プロセスにおける複合粒子成長シミュレーション
}

\author{
岩㟝 智宏, 柳田 㴊, 佐藤 宗武 \\ 大阪府立大学工学部化学工学科, ₹ 599-8531 堺市学園町 1-1.
}

\section{Simulation of Composite Particle Growth in Dispersion and Compounding Process of Alloy Particle and Ceramic Powder}

\author{
Tomohiro Iwasaki, Takeshi Yanagida and Munetake Satoh \\ Dept. Chem. Eng., College of Eng., Osaka Prefecture University, 1-1 Gakuencho, Sakai 599-8531.
}

Received October 8, 1997

\begin{abstract}
SYNOPSIS
In this paper, a compounding process in which fine WC powder was dispersed in particulate Ag-Ni alloy using a high-speed elliptical-rotor-type mill was investigated. In the process, the growth of the composite particle was observed as the processing time proceeds. A model for the growth phenomenon of the particle was constructed by means of theory of powder grinding using ball mill and dynamics of the plastic deformation of metal particle. In the model, the probability that the composite particle grew was adopted. It was expressed as the product of the probability that the particle was caught between a pair of media (zirconia beads), that it occurred the plastic deformation and the number of the rotor caught them, which included the experimental conditions as parameters. Temporal change in size distribution of the composite particles has been calculated using this method. Comparing calculated value with experimental data of particle median diameter, they were in good agreement. Consequently, it has been indicated that the model is valid and accurate estimation and control of particle size were possible.
\end{abstract}

KEY WORDS

composite particle, particle growth, size distribution, simulation

\section{1 緒 言}

各種粉体処理プロセスに扔いて試料粉体の粒度分布の推移を 数式的に記述することができれば,計算によって任意の処理時 間における粒子径を知ることできるので，それに起因する粒子 の物性の制御や目的の状態が得られる時点の予測が可能とな る. 近年, 粉末治金分野においてMAや MGなどの精密微細混 合法を用いて相溶性のない素材同士を機械的に複合化させるプ ロセスに関する研究が盛んに行われているが,複合粒子の物性 に大きな影響を与える粒子径を速度論的に追跡し，定量的な評 価を行った報告はあまり見られない。

著者らはこれまでに， Ag-Ni 合金粒子中にWC微粒子を均一 分散複合化させるプロセスを試料の明度值や粒子径を計測するこ とで評洒し，各種操作条件が複合化に及ほす影響を検討した1.22. また, 本プロセスでは処理時間の経過に伴う複合粒子の成長が 見られたことからこの成長現象に簡単な化学反応モデルを適 用して操作条件之粒子成長速度の関係について検討を行い, 装
置に仕込む試料と媒体の体積比と分散材濃度が複合化に大きな 影響を与えることを定性的に示した2!。

本報では複合粒子の成長現象をより詳細に検討するために， ボールミルを用いた粉碎理論引と金属粒子の塑性変形力学を用 いて，操作条件，粒子の物性および粒子内部の分散材の影響を 考虑した速度論的モデルを構築し，粒度分布の時間的推移をシ ミュレートすることを試みた。

\section{2 粒子成長モデル}

本複合化過程を,試料が複合化媒体であるビーズ間に咬み込 まれ，塑性変形を起こすことによって粒子が成長する確率事象 と考え，粒度分布の時間的変化を物質収支に基づく速度モデル で表現し，以下に示した。

\section{1 速度モデル}

SEM 観察により複合化過程における複合粒子の形状は円板 状であり2，また粒子の厚みの変化が非常に小さいことが確認 
されているので，ここでは粒子を厚みんが一定の円板形とし たモデルを構慗した。

時間 たにおける粒子径 $D_{\mathrm{p}}$ の面積基準の頻度 $f\left(D_{\mathrm{p}}, t\right)\left(\mathrm{m}^{-1}\right)$ は Population balance equation から次式のように表すことができ る.

$$
\frac{\mathrm{d}}{\mathrm{d} t}\left[S(t) \cdot f\left(D_{\mathrm{p}}, t\right) \cdot \mathrm{d} D_{\mathrm{p}}\right]=S_{\mathrm{in}}-S_{\text {out }}
$$

ここで， $S(t)$ は時間 $t$ における粒子の投影面積の総和， $S_{\mathrm{in}}, S_{\text {out }}$ は単位時間当たりに微小粒度区間内 $D_{\mathrm{p}} \sim D_{\mathrm{p}}+\mathrm{d} D_{\mathrm{p}}$ に出入りする 粒子の投影面積である.

また, 粒径 $D_{\mathrm{p}} / \sqrt{2}$ の粒子同士がビーズ間に咬み込まれるこ とによって衝突し，かつ塑性変形することによって粒子成長 が起こり粒径 $D_{\mathrm{p}}$ の粒子が生成する とした簡単なモデル (Fig.1)を導入すると， $S_{\text {in }}, S_{\text {oul }}$ は次のように表すことができる.

$$
\begin{aligned}
& S_{\text {in }}=P_{\mathrm{z}}\left(D_{\mathrm{p}} / \sqrt{2}\right) \cdot S(t) \cdot f\left(D_{\mathrm{p}} / \sqrt{2}, t\right) \cdot \mathrm{d} D_{\mathrm{P}} \\
& S_{\text {out }}=P_{\mathrm{Z}}\left(D_{\mathrm{P}}\right) \cdot S(t) \cdot f\left(D_{\mathrm{p}}, t\right) \cdot \mathrm{d} D_{\mathrm{P}}
\end{aligned}
$$

ここで $P_{\mathrm{z}}\left(D_{\mathrm{p}}\right)$ は粒径 $D_{\mathrm{p}}$ の粒子が単位時間当たりに成長する確 率である。

よって Eqs.(1) (3)より微小粒度区間内 $D_{\mathrm{p}} \sim D_{\mathrm{p}}+\mathrm{d} D_{\mathrm{p}}$ の面積 基準の速度式は次式のようになる。

$$
\begin{aligned}
& \frac{\mathrm{d}}{\mathrm{d} t}\left[S(t) \cdot f\left(D_{\mathrm{P}}, t\right) \cdot \mathrm{d} D_{\mathrm{P}}\right] \\
& \quad=\dot{S}(t)\left[P_{\mathrm{z}}\left(D_{\mathrm{P}} / \sqrt{2}\right) f\left(D_{\mathrm{P}} / \sqrt{2}, t\right)-P_{\mathrm{Z}}\left(D_{\mathrm{P}}\right) f\left(D_{\mathrm{P}}, t\right)\right] \mathrm{d} D_{\mathrm{P}}
\end{aligned}
$$

\section{2 粒子成長確率関数 $P_{z}\left(D_{p}\right)$ の理論的解析}

粒子が成長するためには，2個以上の粒子が互いに衝突する ビーズ間に咬み迟まれ，かつビーズの作用力が粒子を塑性変 形させる力より大きい必要がある。そこで， $P_{\mathrm{z}}\left(D_{\mathrm{p}}\right)$ を粒子が ビーズ間で咬み込まれる確率 $P_{\mathrm{n}}\left(D_{\mathrm{p}}\right)$ と，咬み込まれた粒子が 塑性変形を起こす確率 $P_{\mathrm{pl}}\left(D_{\mathrm{p}}\right)$ の皘で表されるものとして次式 で表した。

$$
P_{\mathrm{Z}}\left(D_{\mathrm{P}}\right)=P_{\mathrm{n}}\left(D_{\mathrm{P}}\right) \cdot P_{\mathrm{P}}\left(D_{\mathrm{P}}\right) \cdot Z
$$

ただし，Zは装置内でローターが単位時間当たりに粉体層を咬

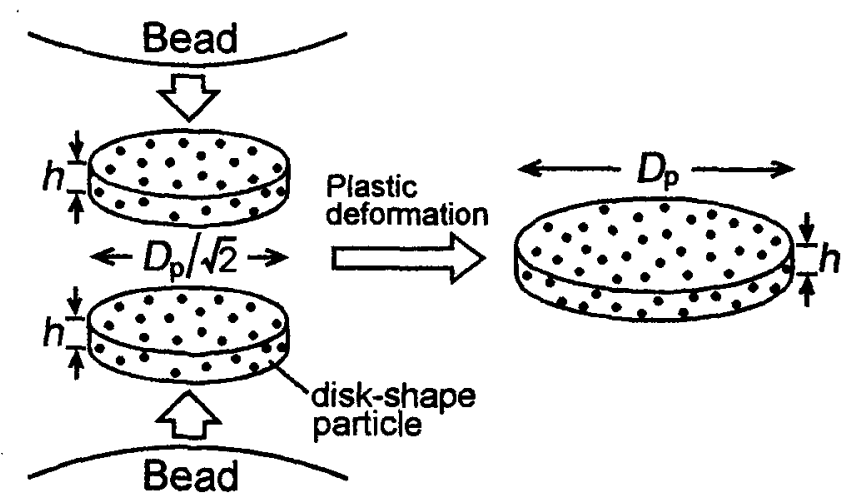

Fig.1 Compounding model of the disk-shape particles.
み込む回数である．以下では Eq.(5)の右辺の各項を導出する.

まず,粒子がビーズ間に咬み込まれる確率関数 $P_{\mathrm{n}}\left(D_{\mathrm{p}}\right)$ は，容 器内に充填された試料の見かけ体積 $V_{\mathrm{a}}$ と，互いに衝突する一 対のビーズ間に咬み込まれる粒子群の見かけ体積 $v_{\mathrm{a}}$ を用いて 以下のように表すことができる3゙.すすなわち，装置内の充填条 件を考えると $V_{\mathrm{a}}$ は

$$
V_{\mathrm{a}}=V_{\mathrm{m}} f \frac{V_{\mathrm{p}} / V_{\mathrm{b}}}{1+V_{\mathrm{p}} / V_{\mathrm{b}}}
$$

で与えられる，ここで， $V_{\mathrm{m}}$ は装置内有効容積， $f$ は装置内充 填率、 $V_{\mathrm{p}}, V_{\mathrm{b}}$ はそれぞれ試料とビーズの見かけ仕込み体積であ る、また，ビーズ間の二粒子はビーズによって比較的小さな 作用力で速やかに接触して見かけ上一つの粒子になるとする と，衝突する一対のビーズ間に咬み込まれる粒子の見かけ体 積 $v_{\mathrm{a}}$ は試料とビーズの粒子径をそれぞれ $D_{\mathrm{p}}, D_{\mathrm{o}}$ で表すと Fig.2 から幾何学的に次式で与えられる。

$$
\begin{aligned}
v_{\mathrm{a}} & =\pi b^{2} D_{\mathrm{p}} \\
b^{2} & \cong \frac{1}{2} D_{\mathrm{p}} D_{\mathrm{b}}
\end{aligned}
$$

一方，Fig.2に示すように，衝突するビーズ間に粒子が咬み込 まれたとき，粒子には咬み込まれる内向きの力 $\mu \mathrm{Fcos}^{2} \theta$ と外側 にはじき飛ばされる外向きの力 $F \cos \theta \sin \theta か ゙$ 同時に㗢くことに なる.ここで， $\mu$ はビーズと粒子の動摩擦係数であり，Fは ビーズの衝突によって生ずる作用力である．内向きの力が外 向きの力に比べて大きい場合に粒子はビーズ間に咬み达まれ るものと考えると，粒子が咬み込まれる条件は

$$
\mu F \cos ^{2} \theta \geq F \cos \theta \sin \theta
$$

すなわち

$$
\tan \theta \leq \mu
$$

で表わされる，よって，粒子がはじき飛ばされずに咬み込ま れる範囲と，粒子が作用力を受ける範囲との面積比 $\xi=\tan ^{-1} \mu$ とすると

$$
r=\frac{\left[\left(D_{\mathrm{b}} / 2\right) \tan \xi\right]^{2}}{b^{2}}=\frac{\mu^{2}}{2}\left(\frac{D_{\mathrm{b}}}{D_{\mathrm{P}}}\right)
$$

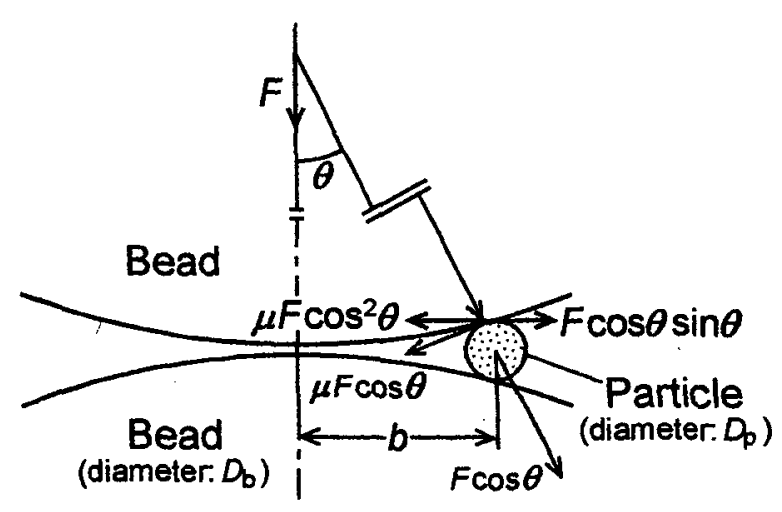

Fig.2 Schematic of a composite particle caught between a pair of beads. 
となる，したがって，粒子の咬み込み確率関数 $P_{\mathrm{n}}\left(D_{\mathrm{p}}\right)$ は次式 のように表される。

$$
P_{\mathrm{n}}\left(D_{\mathrm{p}}\right)=\frac{\nu_{\mathrm{a}}}{V_{\mathrm{a}}} \times r=\frac{\pi \mu^{2} D_{\mathrm{p}} D_{\mathrm{b}}^{2}}{4 V_{\mathrm{m}} f}\left(\frac{V_{\mathrm{p}} / V_{\mathrm{b}}}{1+V_{\mathrm{p}} / V_{\mathrm{b}}}\right)^{-1}
$$

ここまでの $P_{n}\left(D_{p}\right)$ の解析では粒子を球形としていたが，本 モデルにおいては粒子を円板形としているので，このことを 考慮して形状補正保数 $\phi$ を導入すると次式を得る。

$$
P_{\mathrm{n}}\left(D_{\mathrm{p}}\right)=\frac{\pi \mu^{2} D_{\mathrm{p}} D_{\mathrm{b}}^{2}}{4 V_{\mathrm{m}} f}\left(\frac{V_{\mathrm{p}} / V_{\mathrm{b}}}{1+V_{\mathrm{p}} / V_{\mathrm{b}}}\right)^{-\phi}
$$

ただし，形状補正係数 $\phi$ は

$$
\phi=\frac{\text { 円板粒子の投影面皘 }}{\text { 円板粒子と同体積の球粒子の投影面皘 }}
$$

の形で表せるものとする.

次に，ビーズ間に咬み込まれた粒子が塑性变形する確率関 数 $P_{\mathrm{p} 1}\left(D_{\mathrm{p}}\right)$ は，塑性変形に必要な応力 $p$ を求めることによって 得られる.Fig.3に示した円板粒子(厚さ $h$ )の微小部分におけ る半径方向の力のバランスを考えると次のようになる゙).

$$
\begin{aligned}
& \sigma_{\mathrm{r}} h r \mathrm{~d} \theta-\left(\sigma_{\mathrm{r}}+\mathrm{d} \sigma_{\mathrm{r}}\right) h(r+\mathrm{d} r) \mathrm{d} \theta \\
& \quad+2 \sigma_{0} h \mathrm{~d} r \sin (\mathrm{d} \theta / 2)-2 \pi r \mathrm{~d} \theta \mathrm{d} r=0
\end{aligned}
$$

また, $\sin (\mathrm{d} \theta / 2) \approx \mathrm{d} \theta / 2$ と近似すると

$$
\left(\sigma_{\mathrm{r}} h-\sigma_{\theta} h+2 \tau r\right) \mathrm{d} r+r h \mathrm{~d} \sigma_{\mathrm{r}}=0
$$

ここで，粒子を理想塑性体と仮定すると Levy-Mises equation ${ }^{5}$ より $\sigma_{\theta}=\sigma_{\mathrm{r}}$ となり，また，剪断応力 $\tau$ はビーズと粒子の全接 触面が付着摩擦状態ににあると仮定することによってvon Mises の降伏条件 ${ }^{6}$ から

$$
\tau=-\sigma_{0} / \sqrt{3}
$$

$\left(\sigma_{0}:\right.$ 粒子の降伏応力) で表されるので, Eq.(16) より次式が得 られる。

$$
\frac{\mathrm{d} \sigma_{\mathrm{r}}}{\mathrm{d} r}-\frac{2 \sigma_{0}}{\sqrt{3} h}=0
$$

端面の剪断応力の影響を無梘すると $\sigma_{0}$ は

$$
\sigma_{\mathrm{r}}=\sigma_{0}-p
$$

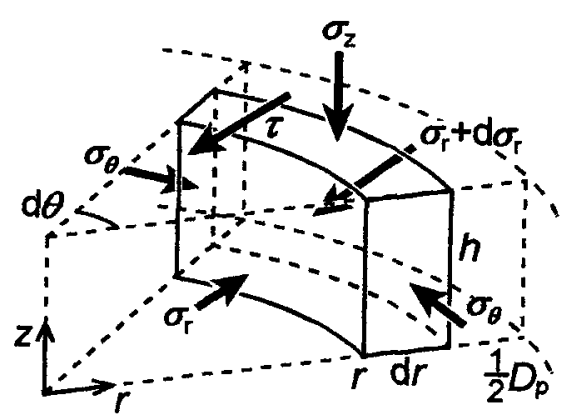

Fig.3 Stresses acting on compression of sector of disk-shape particle.
で与えられるので，Eq.(19)を Eq.(18)に代入して境界条件 $r=D_{\mathrm{p}} / 2, p=\sigma_{0}$ を用いて解くと

$$
p=\sigma_{0}\left[1+\frac{2}{\sqrt{3} h}\left(\frac{D_{\mathrm{P}}}{2}-r\right)\right]
$$

となる．また，円板粒子が塑性変形するのに必要な平均変形 応力 $\bar{p}$ は次式のようになる。

$$
\bar{p}=\frac{\int_{0}^{D_{\mathrm{p}} / 2} 2 \pi p r \mathrm{~d} r}{\pi D_{\mathrm{P}}{ }^{2} / 4}=\sigma_{0}\left(1+\frac{D_{\mathrm{P}}}{3 \sqrt{3} h}\right)
$$

このように, $\bar{p}$ が粒径 $D_{\mathrm{p}}$ に比例していることから，粒子表面 に平均的な応力が加わっているものとすると， $P_{\mathrm{pl}}\left(D_{\mathrm{p}}\right)$ は $D_{\mathrm{p}} に$ 対する減少関数となっていると推測される。 そこで, ビーズ から粒子が受ける作用力 $F$ をーターの円運動から半径方向 の遠心力 $m r \omega^{2}$ とし，この力と等しい $\mathrm{Eq} .(22)$ に示すような減少関数を $P_{\mathrm{pl}}\left(D_{\mathrm{p}}\right)$ に適用することによっ て塑性変形確率を求めることにした。

$$
P_{\mathrm{P} 1}\left(D_{\mathrm{P}}\right)=k D_{\mathrm{P}}^{-8\left(C_{\mathrm{wC}}\right)}
$$

ただし, $k$ は物性に依存する定数, $g\left(C_{\mathrm{wc}}\right)$ は分散材粒子濃度が 塑性変形に与える影響度である。

粒子分散強化型合金においては材料の弾性率および強さは 分散粒子の体積比に比例し，また分散材濃度の増加に伴って 塑性変形に必要な転位の動きが阻害される7ことを考虑して， ここでは $g\left(C_{\mathrm{wc}}\right)$ を次式のように最も簡単な形で表した。

$$
g\left(C_{\mathrm{wc}}\right)=\alpha+\beta \cdot C_{\mathrm{wC}}
$$

ここで， $\alpha, \beta$ は物性に依存する定数である.

最後に，単位時間当たりにローターが粉体層を咬み込む回 数Zはローターの回転速度 $N_{\mathrm{r}}$ と容器回転速度 $N_{\mathrm{v}}$ を用いて次式 で与えられる。

$$
Z=2\left(N_{\mathrm{r}}+N_{\mathrm{v}}\right)
$$

したがって，粒子成長確率関数 $P_{z}\left(D_{\mathrm{p}}\right)$ は Eqs.(13)，(22), (24) を Eq.(5)に代入することによって求められ，これを Eq.(4)に 代入すると粒度分布の経時変化を求めることができる。

\section{3 実験方法}

本実験で取り上げた複合化過程は，前報1.2) 同様，高速楕円 ローター型ミルを委用いて Ag-Ni 合金粒子中にWC微粒子を 均一分散複合化させるプロセスである．実験では，装置に所 定の割合に配合した試料粉体を複合化媒体であるジルコニア ビーズとともに容器体皘装入率 $f=0.2$ となるように仕込み， 容器回転速度 $N_{\mathrm{v}}=1.67 \mathrm{~s}^{-1}$ 一定として, 試料粉体とビーズの体 積比率 $V_{\mathrm{p}} V_{\mathrm{b}}(0.3 \sim 1.5)$, 分散材濃度 $C_{\mathrm{wc}}(1 \sim 10 \mathrm{wt} \%)$, ローター 回転速度 $N_{\mathrm{r}}\left(25.0 \sim 41.7 \mathrm{~s}^{-1}\right)$, ビーズ径 $D_{\mathrm{b}}(300 \sim 1000 \mu \mathrm{m})$ 等の各 種操作条件を変更しながら複合化処理を行った，測定時間毎 に試料をサンプリングして実体顕微鏡で観察し，その粒度分 布を画像解析装置で測定した。測定は 50 視野(粒子数：約 5000 


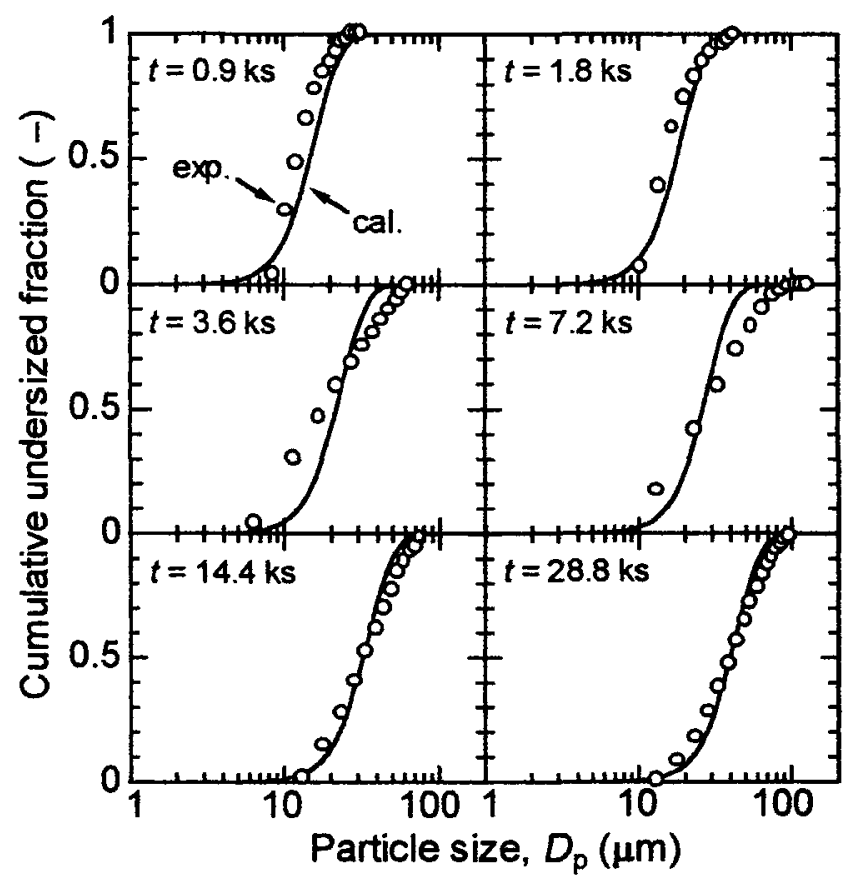

Fig.4 Change in size distribution curves with the processing time, t. $\left(C_{\mathrm{wC}}=0.10, D_{\mathrm{b}}=1000 \mu \mathrm{m}, N_{\mathrm{t}}=41.7 \mathrm{~s}^{-1}, V_{\mathrm{p}} / V_{\mathrm{b}}=0.3\right)$

個以上)に対して行った。

なお，粒度分布の計算に必要な定数 $k, \alpha, \beta$ は，いくつかの 操作条件下で行った粒子複合化実験 ${ }^{2)}$ 上り， $k=5.00 \times 10^{4}$, $\alpha=14.2, \beta=3.54$ と決定し, 本モデルは以下の仮定に従うもの とした

（1） $t=0$ でWC分散材は粉体層中に場所的に一様に分布してい る.

(2) 粒子は円板形で密度は一定である.

（3）粒子の降伏応力は分散材濃度のみに依存する.

\section{4 計算および実験結果と考察}

4.1 粒度分布変化

Fig.4に複合粒子の粒度分布の時間的変化の計算および実験 結果の一例を示した，処理初期においては時間の経過に従い 粒子の塑性変形に伴う成長現象が顕著となり，粒度分布は粒 子径の大きい方へ推移している，その後塑性変形に必要な力 と粒子への作用力との力の釣り合いから粒子径は定常值を示 しており，これらの現象を計算により表すことができた．粒 度分布の幅が比較的大きくなる処理初期を除き，各時間にお ける実験結果と計算結果は扔执むね一致しており，本モデル は実際の粒子成長現象をうまく表現しているといえる.また， 計算より得られた粒度分布から算出した中位径 $D_{50}$ と実験結果 から得られたものを比較した一例を Fig.5に示した，図のよう に中位径の時間的変化の計算結果と実験結果はほほ一致して いるので，以下では両者の比較を中位径の時間変化を用いて 行うことにした。

4.2 各種操作条件の影響

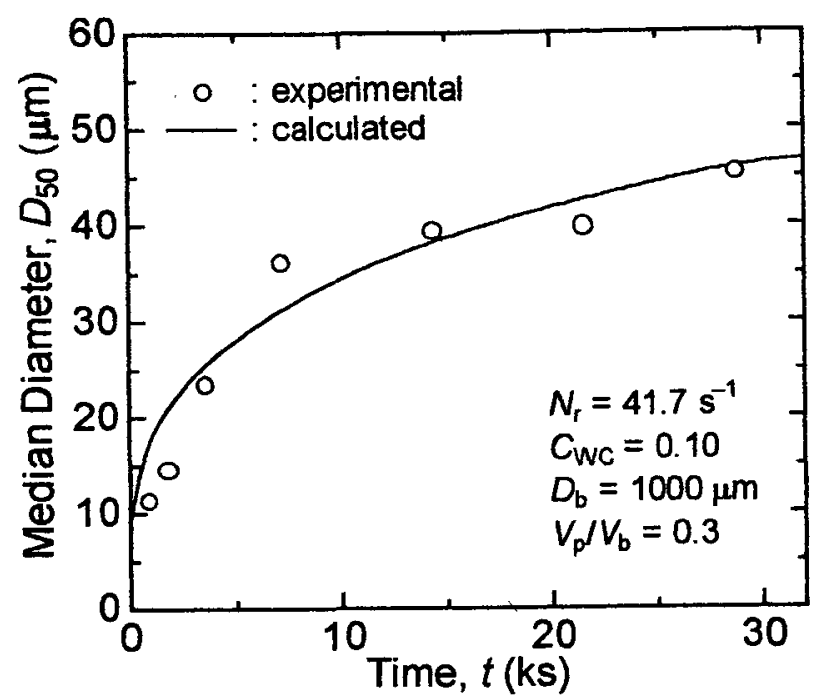

Fig.5 Change in $D_{50}$ with the processing time, $t$.

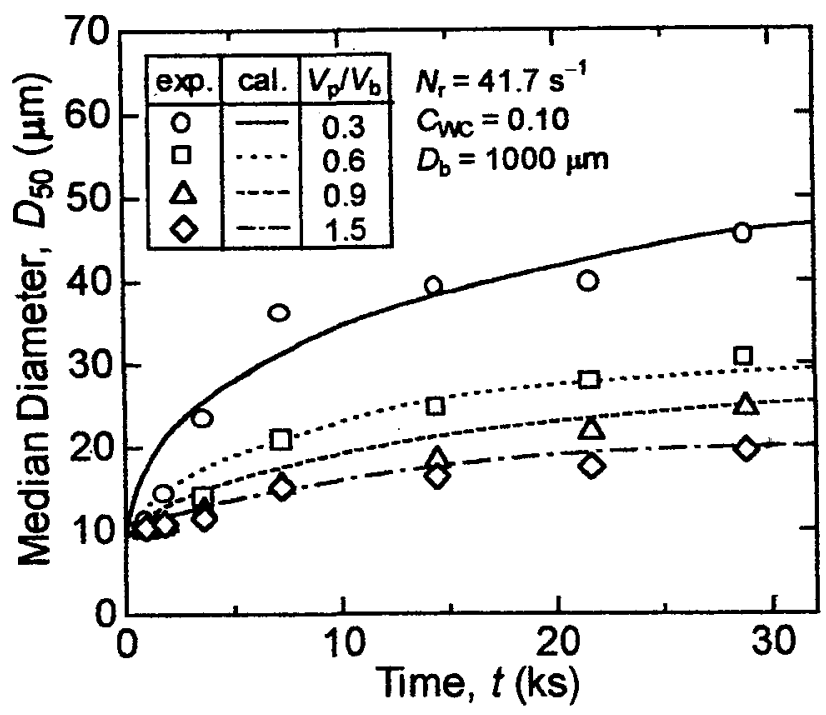

Fig.6 Effect of the volume ratio, $V_{\mathrm{p}} / V_{\mathrm{b}}$, on the temporal change in $D_{50}$.

まず前報りで示したように，複合粒子の成長速度に大きな 影響を及ぼす粉体とビーズの仕込み体積比 $V_{\mathrm{p}} / V_{\mathrm{b}}$ を変化させて 計算および実験を行った. Fig.6には体積比 $V_{\mathrm{p}} \boldsymbol{J}_{\mathrm{b}}$ をパラメー 夕として複合粒子の中位径 $D_{50}$ と処理時間 $t$ との関係を示し た。 $V_{\mathrm{p}} / V_{\mathrm{b}}$ が大きいほど試料がビーズ間で咬み込まれる確率 $P_{\mathrm{n}}\left(D_{\mathrm{p}}\right)$ が小さくなることから, 計算および実験結果ともに粒 子成長速度が低下する傾向を示しており，これらの間には良 好な一致が見られた，このことから，粒子成長確率に粒子の 咬み込み確率を考慮した本モデルの妥当性が示されたといえ る.

次に，粒子の塑性変形に対して大きな影響を与える複合粒 子内部の分散材濃度について検討した. Fig.7には分散材濃度 $C_{\mathrm{wc}}$ を変化させた場合の $D_{50}$ の時間的変化の計算および実験結 果を示した， $C_{\mathrm{wc}}$ の増加に伴って処理終期における複合粒子 


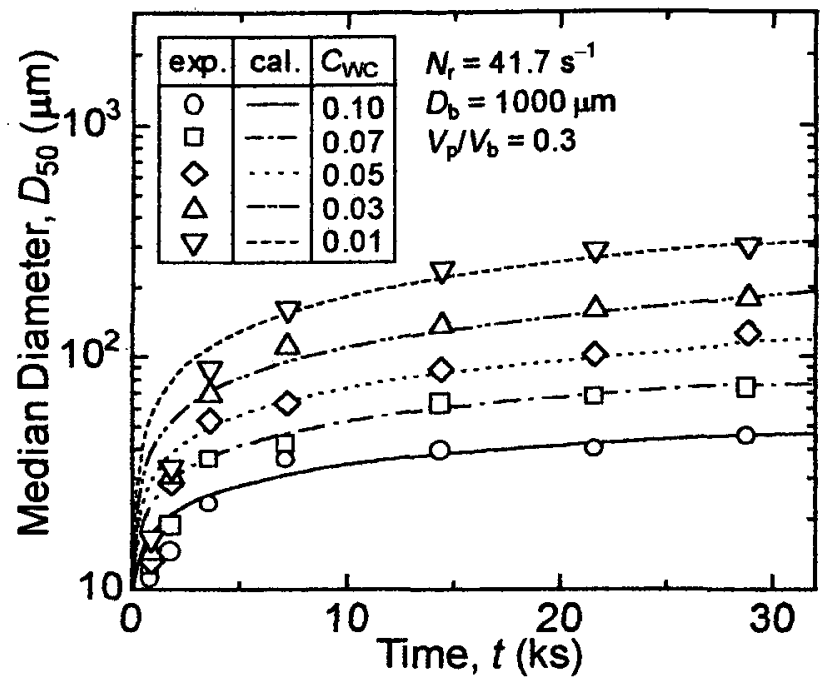

Fig.7 Effect of WC concentration, $C_{\mathrm{Wc}}$, on the temporal change in $D_{s 0}$.

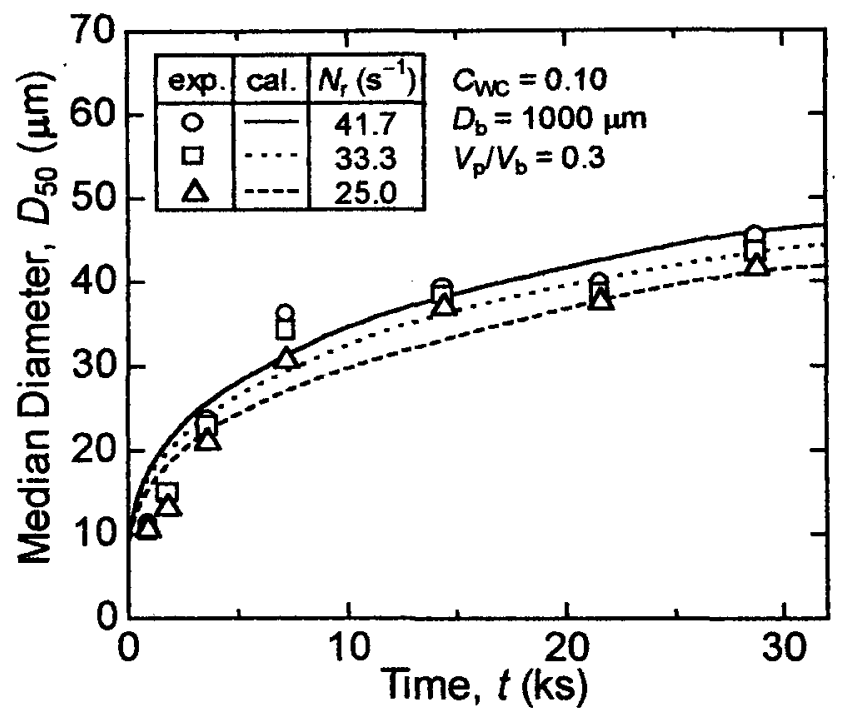

Fig.8 Effect of the rotor speed, $N_{\mathrm{r}}$, on the temporal change in $D_{50}$.

径は小さくなっており，これは前述したように分散材粒子の 存在が粒子成長に必要な塑性変形を阻害していることが主な 原因であると思われる，また，計算および実験值はほほ一致 しており，ここでも分散材濃度が粒子の塑性変形に及ほす影 響を考慮したモデルの妥当性が示された。

また，粉体層に圧縮・剪断作用を与えているローターの回 転速度 $N_{r}$ の影響について検討するため, $N_{r}$ を変化させて計算 ならびに実験を行い，その結果を Fig.8に示した， $N_{r}$ が大きい ほど単位時間当たりの粉体層の咬み込み回数が増加するため に，計算と奏験結果ともに粒子成長速度は速くなる傾向を示 しており，而者間で良好な一致が見られた。しかし，この結 果と $V_{\mathrm{p}} / V_{\mathrm{b}}$ を変化させた結果 (Fig.6) を比較すると，そのパラ メータによる差異は $V_{\mathrm{p}} / V_{\mathrm{b}}$ の方が大きく現れていることから， ローターの回転速度が大きいときローターが粉体層をより多

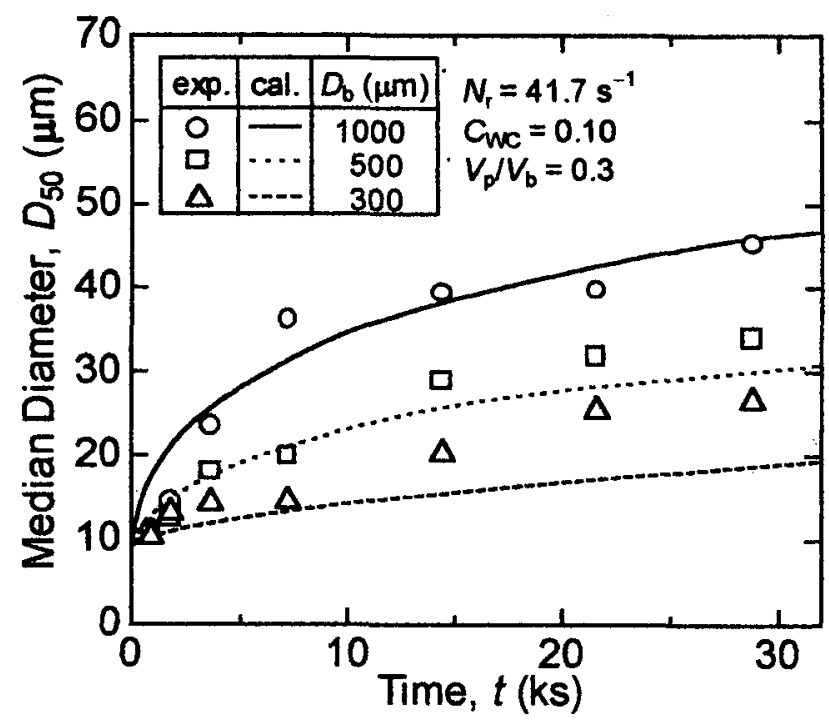

Fig.9 Effect of the bead diameter, $D_{b}$, on the temporal change in $D_{50}$.

く咬み込むとしても，咬み込まれた粉体層中に塑性変形に必 要な量のビーズが存在しないならば複合粒子の成長が起こら ないことを示しており,このことを本モデルによって表現す ることができた。

最後に，複合化媒体であるビーズの粒径が複合粒子の成長 に及ぼす影響を検討した、ビーズを微小化することによって， 複合粒子が受ける応力や咬み込み確率が変化することから複 合粒子を微粒子化することが推測される9!.そこで,ビーズ径 $D_{6}$ を変化させた場合の計算ならびに実験を行い，Fig.9にその 結果を示した。 D が微小なほど複合粒子は微粒子化される傾 向が計算および実験ともに見られたが，D品が小いほど計算 值と実験值との間に差異が生じており，今後さらに検討する 必要がある.

\section{5 結 言}

合金粒子中にセラミックス微粒子を均一分散複合化させる プロセスにおいて，金属粒子の塑性変形に伴う粒子の成長現 象を速度論的に解析し，その機構について検討した結果，以 下に示す知見を得た。

1）複合化過程における粒子成長を，試料粉体が複合化媒体 (ビーズ)に咬み込まれ，塑性変形を起こす確率事象とし， 複合粒子の成長確率関数を粒子の咬み込み確率, 塑性変形 確率および粉体層の咬み込み回数の積として表しモデル化 することができた。

2) 塑性変形による粒子成長機構を粉体と媒体の体積比率, 分 散材濃度, ローター回転速度, 媒体径等の重要な影響团子 に対して検討し，モデルの妥当性を計算と実験から示し た。

3）本モデルにより塑性変形造粒を伴う分散複合化過程におけ る複合粒子の粒子径の経時变化を計算により求めることが 可能となった。 


\section{文献}

1) 佐藤宗武, 柳田剛, 岩暗智宏: "Ag-Ni粒子とWC微粒子の 高速楕円ローター型ミルによる分散複合化過程",粉体お よび粉末治金, 44(1997)618-621.

2）岩嵪智宏，柳田剛，佐藤宗武："粉末金属の複合化過程に おける粒子径変化に及ほすす操作条件の影響”, 粉体および 粉末治金, 45(1998)271-275.

3）桑原好䒚, 藤文良, 八嶋三郎："振動ミルの選択関数に 関する一解析 ", 粉体工学研究会誌, 14(1977)319-325.

4) G.E.Dieter: Mechanical Metallurgy, 3rd Ed., McGraw-Hill, Inc. (1986)539.

5) G.E.Dieter: Mechanical Metallurgy, 3rd Ed., McGraw-Hill, Inc.
(1986)90.

6) G.E.Dieter: Mechanical Metallurgy, 3rd Ed., McGraw-Hill, Inc. (1986)77.

7) 福田博, 横田力男, 塩田一路：複合材料基礎工学, 日刊工 業新聞社, (1994)160.

8）佐藤宗武, 吉田達守, 宮南啓, 奥平有三："高速楕円ロ夕ー型粉体混合装置の特性", 粉体工学会誌, 31(1994)789794.

9）山内克久,朴容浩, 橋本等, 渡辺龍三: “层動ボールミリン グによるTi-Alのメカニカルアロイング過程におけるミリ ング粉末粒子の形態と物性の変化", 粉体および粉末治金, 38(1991)42-46. 